\title{
Yield and Some Quality Properties of Binary Alfalfa-Grass Mixtures in Different Mixture Ratios
}

\author{
Osman Yüksel ${ }^{1, a, *}$, Cahit Balabanlı ${ }^{2, b}$ \\ ${ }^{I}$ Department of Field Crops, Faculty of Agriculture, Usak University, 64000 Usak, Turkey \\ ${ }^{2}$ Department of Field Crops, Faculty of Agriculture, Isparta University of Applied Sciences, 32200 Isparta, Turkey
}

${ }^{*}$ Corresponding author

\section{A R T I C L E I N F O A B S T R A C T}

Research Article

The aim of this investigation was to determine appropriate perennial grasses and their most suitable mixture ratios, which can be grown with alfalfa in binary mixtures. The research was conducted during 2009-2011 in Isparta $\left(37.50{ }^{\circ} \mathrm{N}, 30.32^{\circ} \mathrm{E}\right)$, located in the Western Mediterranean climate conditions. In the study, alfalfa was planted as a binary mixture with perennial ryegrass (Lolium perenne L.), orchardgrass (Dactylis glomerata L.), meadow fescue (Festuca pratensis Huds.), and smooth bromegrass (Bromus inermis Leyss.) in a randomized block design with three replications. Sowing ratios of alfalfa in the mixtures varied 20,30 , and $40 \%$, and grass species ratios were 80 , 70 , and $60 \%$. In the study, significant differences were found among the applications regarding hay yield, crude protein content, crude protein yield, NDF, ADF, land equivalent ratio (LER), and grass ratio in the hay (GR). The highest hay yield was obtained from alfalfa + orchardgrass and alfalfa +

Keywords: smooth bromegrass binary mixtures $\left(25.98\right.$ and $25.78 \mathrm{t} \mathrm{ha}^{-1}$, respectively). Alfalfa + perennial ryegrass and alfalfa + meadow fescue mixtures gave the highest crude protein contents as 14.93 and

Grass

Binary mixture

Yield

$14.80 \%$, respectively. The highest LER values were observed on perennial ryegrass and smooth bromegrass binary mixtures, and the highest grass ratios were determined in orchardgrass and Land equivalent ratio smooth bromegrass mixtures made with alfalfa. Increasing the alfalfa sowing ratio in the mixtures positively affected all quality characteristics such as crude protein, NDF, and ADF. It was concluded that orchardgrass and smooth bromegrass binary mixtures with alfalfa produced high yield and quality hay and that the mixture should contain $40 \%$ alfalfa and $60 \%$ grass.

osman.yuksel@usak.edu.tr (iD) https://orcid.org/0000-0002-5972-4885

b@cahitbalabanli@isparta.edu.tr

https://orcid.org/0000-0001-8894-6244

(c) (1) ) (9) This work is licensed under Creative Commons Attribution 4.0 International License

\section{Introduction}

Growing forage crops in a mixture have many advantages over pure plantings. Since root and branch spreads of plants are different in legume and grass mixtures, soil and light are better used. Besides, nitrogen fixed in legume roots is used by grasses. For this reason, mixes are superior to pure sowings in terms of yield (Ta and Faris, 1987; Dhima et al., 2007). Although the ecological demands of the species in the mixtures are different, the plants in the mixtures can inevitably compete with each other. Therefore, the species to be included in the mixtures should be selected very well. Otherwise, mixtures of incompatible plants cannot provide the expected benefits (Sheaffer et al., 1981; Coulman, 1987). Since the competitive power of the mixture components is different, unwanted changes may occur over time after all one of the species can suppress the other. Mixtures of alfalfa with perennial grasses produce more balanced roughage in terms of crude protein and carbohydrates. In this way, mixtures eliminate the adverse effects that may arise in animals due to swelling or one-way feeding.
Alfalfa is one of the most commonly used legumes for both hay and pasture in Turkey because of its high yield, high nutritional quality, ability to fix nitrogen and vigorous fall regrowth (Acikgoz, 2001). Moreover, alfalfa is highly resistant to high summer temperatures in both arid and irrigable conditions. Therefore specifically cool-season grasses are positively affected by the mixtures made with alfalfa in terms of yield and quality. Cecen et al. (2005) reported that the yields of alfalfa and smooth bromegrass mixtures were higher than pure plantings also pure plantings of smooth bromegrass and perennial ryegrass were negatively affected by high summer temperatures. Celiktas et al. (2003) reported that the mixtures made with alfalfa were more efficient in mixes of alfalfa, white clover and red clover, and smooth bromegrass, orchardgrass, and perennial ryegrass. Moreover, Amendola et al. (1997) stated that in the mixtures of alfalfa and birdsfoot trefoil with orchardgrass, perennial ryegrass, and tall fescue, the highest yields were obtained from the mixes of alfalfa- 
orchardgrass $\left(22.41 \mathrm{t} \mathrm{ha}^{-1}\right)$ and alfalfa-tall fescue $(21.35 \mathrm{t}$ $\left.\mathrm{ha}^{-1}\right)$. In a study carried out under irrigable conditions in Diyarbakir, alfalfa, crested wheatgrass, orchardgrass, timothy, smooth bromegrass, and meadow fescue were planted in pure and binary mixtures. According to the twoyear average results, the highest hay yield was obtained from the mixture of alfalfa-smooth bromegrass, while the lowest hay yield was obtained from smooth bromegrass (Basbag et al., 2007).

In this research, it is aimed to determine some perennial grasses and their most suitable mixture ratios that can be grown in binary mixtures with alfalfa under irrigable conditions in Isparta.

\section{Materials and Methods}

\section{Site Description}

This research was conducted during 2009-2011 in Isparta $\left(37.50^{\circ} \mathrm{N}, 30.32^{\circ} \mathrm{E}\right)$, south-western Turkey, located at about $1014 \mathrm{~m}$ altitude above the sea level. The soil of the experimental area was slightly alkaline $(7.65 \mathrm{pH})$, low in organic matter $(0.82 \%)$, moderate in phosphorus content $\left(11.48 \mathrm{~kg} \mathrm{ha}^{-1}\right)$, but rich in potassium content $(161.55 \mathrm{~kg} \mathrm{ha}$ $\left.{ }^{1}\right)$ at the depth of $30 \mathrm{~cm}$. The total rainfall of the experimental area was $628.8 \mathrm{~mm}$ in 2010 and $400.0 \mathrm{~mm}$ in 2011 years. The annual average temperature was 14.1 and $12.1^{\circ} \mathrm{C} 2010$ and 2011 years respectively (Table 1).

\section{Experimental Design and Crop Management}

Alfalfa (Medicago sativa L.) (cv. Altiva) was grown with perennial ryegrass (Lolium perenne L.) (cv. Bizet), orchardgrass (Dactylis glomerata L.) (cv. Amba), meadow fescue (Festuca pratensis Huds.) (cv. Senu), and smooth bromegrass (Bromus inermis Leyss.) (population) in binary mixtures in randomized block design with three replications. The binary mixtures were sown in 20,30, and $40 \%$ alfalfa, and 80,70 , and $60 \%$ grass, mixture ratios in alternative rows. The row spacing in the plots was $30 \mathrm{~cm}$ (Altin and Gokkus, 1988), and each plot was 6 rows of $5 \mathrm{~m}$ in length. The seeding rates were $20 \mathrm{~kg} \mathrm{ha}^{-1}$ for alfalfa, meadow fescue, and smooth bromegrass and $30 \mathrm{~kg} \mathrm{ha}^{-1}$ for orchardgrass and perennial ryegrass. Sowing was performed by hand on 11 April 2009. Fertilizer rates of 100 $\mathrm{kg} \mathrm{ha}^{-1} \mathrm{~N}$ and $\mathrm{P}$ were applied at sowing and $50 \mathrm{~kg} \mathrm{ha}^{-1} \mathrm{~N}$ and $\mathrm{P}$ were applied in 2010 and 2011 (Atis and Hatipoglu,
2008). Plots were irrigated with sprinkler irrigation at intervals of 7-10 days, depending on the soil moisture. Harvest was made when the alfalfa in the mixtures was at 10\% bloom stage (Gokkus et al., 1999). The harvests made in 2009 were excluded from the evaluation, and four harvests were made in 2010 and 2011 each.

\section{Forage Quality and Statistical Analysis}

Collected samples following each harvest were hand separated, dried at $70^{\circ} \mathrm{C}$ for $48 \mathrm{~h}$, and weighed. The dried samples were reassembled and ground to pass through a 1 $\mathrm{mm}$ screen. The crude protein content was calculated by multiplying the Kjeldahl nitrogen concentration by 6.25 (Kacar and Inal, 2008). NDF (neutral detergent fiber) and ADF (acid detergent fiber) concentrations were analyzed according to standard laboratory procedures for forage quality analysis Ankom Technology, (Anonymous, 2010). Crude protein content, ADF, and NDF analyzes were made separately for each cutting and species, and the total values were calculated according to the formula below.

The crude protein content of the mixture plots (for each cutting): (Crude protein content of alfalfa x Ratio of alfalfa in hay) + (Crude protein content of grass $x$ Ratio of grass in hay).

Total crude protein ratio: $\left(1^{\text {st }}\right.$ cutting crude protein content $(\%) \times 1^{\text {st }}$ cuttings share in total $\left.(\%)\right)+\left(2^{\text {nd }}\right.$ cutting crude protein content $(\%) \times 2^{\text {nd }}$ cuttings share in total (\%)) $+\left(3^{\text {rd }}\right.$ cutting crude protein content $(\%) \times 3^{\text {rd }}$ cuttings share in total $(\%))+\left(4^{\text {th }}\right.$ cutting crude protein content $(\%) \times 4^{\text {th }}$ cuttings share in total (\%)).

The land equivalent ratio (LER) was used as an index for mixed stand advantage for both alfalfa and grass. LER values were calculated as the following formula (Willey and Osiru, 1972).

$$
\begin{aligned}
& \mathrm{LER}=(\mathrm{Yij} / \mathrm{Yii})+(\mathrm{Yji} / \mathrm{Yjj}) \\
& \mathrm{Yij}=\text { Yield of alfalfa under mixed stand conditions } \\
& \mathrm{Yji}=\text { Yield of grass under mixed stand conditions } \\
& \mathrm{Yii}=\text { Yield of alfalfa under sole crop conditions } \\
& \mathrm{Yjj}=\text { Yield of grass under sole crop conditions }
\end{aligned}
$$

The data, obtained from the study were analyzed using

\begin{tabular}{|c|c|c|c|c|c|c|}
\hline \multirow{2}{*}{ Months } & \multicolumn{3}{|c|}{ Precipitation (mm) } & \multicolumn{3}{|c|}{ Temperature $\left({ }^{\circ} \mathrm{C}\right)$} \\
\hline & $1947-2010$ & 2010 & 2011 & 1947-2010. & 2010 & 2011 \\
\hline January & 64.2 & 68.0 & 34.6 & 1.7 & 4.2 & 2.9 \\
\hline February & 54.9 & 136.8 & 51.8 & 2.6 & 5.7 & 3.7 \\
\hline March & 52.8 & 33.2 & 50.4 & 5.9 & 8.7 & 6.3 \\
\hline April & 58.8 & 47.0 & 54.7 & 10.5 & 11.9 & 10.3 \\
\hline May & 46.0 & 32.4 & 43.1 & 15.5 & 17.1 & 14.4 \\
\hline June & 27.8 & 64.5 & 62.2 & 20.1 & 19.2 & 19.8 \\
\hline July & 12.8 & 40.1 & 1.8 & 23.4 & 24.8 & 25.0 \\
\hline August & 0.3 & 0.2 & 0.6 & 25.8 & 27.0 & 24.5 \\
\hline September & 15.4 & 29.7 & 13.2 & 18.3 & 20.3 & 20.3 \\
\hline October & 38.0 & 79.1 & 50.4 & 12.8 & 12.7 & 11.1 \\
\hline November & 51.5 & 13.6 & 0.2 & 6.9 & 10.8 & 4.2 \\
\hline \multirow[t]{3}{*}{ December } & 70.9 & 84.2 & 37.0 & 3.0 & 6.8 & 2.5 \\
\hline & \multicolumn{3}{|c|}{ Total } & \multicolumn{3}{|c|}{ Mean } \\
\hline & 493.4 & 628.8 & 400.0 & 12.3 & 14.1 & 12.1 \\
\hline
\end{tabular}
the JMP 10.0.0 computer software program at the $\mathrm{P} \leq 0.05$ and 0.01 levels of significance, and means were compared using the least significant difference test at $\mathrm{P}<0.05$.

Table 1 . Monthly precipitation and mean temperature in the experimental area. 
Table 2. Results of analysis of variance and mean squares of the traits determined.

\begin{tabular}{lc|ccccccc}
\hline \multirow{2}{*}{ Sources of Variation } & \multirow{2}{*}{ Df } & \multicolumn{7}{c}{ Mean Square } \\
\cline { 3 - 8 } & & Hay yield & CP & CP yield & NDF & ADF & LER & GR \\
\hline Year & 1 & $50.85^{* *}$ & $8.49^{* *}$ & $3.11^{* *}$ & $94.34^{* *}$ & 0.058 & $0.13^{* *}$ & $2358^{* *}$ \\
Block (Year) & 4 & 0.91 & 0.18 & 0.04 & 0.07 & 0.207 & $0.11^{* *}$ & 12.3 \\
Mixture (M) & 3 & $33.23^{* *}$ & $3.91^{* *}$ & 0.20 & $18.48^{* *}$ & $1.213^{* *}$ & $0.54^{* *}$ & $196.9^{* *}$ \\
M $\times$ Y int. & 3 & $19.40^{* *}$ & 0.27 & $0.44^{* *}$ & $1.39^{*}$ & $1.365^{* *}$ & $0.06^{*}$ & $159.1^{* *}$ \\
Mixture Rate (MR) & 2 & $16.25^{* *}$ & $1.343^{* *}$ & $0.77^{* *}$ & $9.26^{* *}$ & $2.050^{* *}$ & 0.05 & $777.2^{* *}$ \\
MR Y int. & 2 & 0.85 & 0.08 & 0.03 & $3.34^{* *}$ & 0.030 & 0.001 & $70.2^{* *}$ \\
M $\times$ MR int & 6 & 1.77 & 0.08 & 0.05 & $1.30^{*}$ & $0.547^{*}$ & 0.009 & $26.5^{* *}$ \\
M $\times$ MR $\times$ Y int. & 6 & 1.62 & 0.12 & 0.04 & 0.22 & 0.244 & 0.003 & 2.8 \\
Error & 44 & 3.06 & 0.10 & 0.08 & 0.44 & 0.23 & 0.019 & 5.9 \\
\hline CV (\%) & & 7.07 & 2.20 & 7.86 & 1.36 & 1.45 & 10.07 & 10.60 \\
\hline
\end{tabular}

Df, degree of freedom; CP, crude protein ratio; NDF, neutral detergent fiber; ADF, acid detergent fiber; LER, land equivalent ratio; GR, grass ratio; $\mathrm{CV}$, coefficient of variation; ${ }^{*} \mathrm{P} \leq 0.01 ; * \mathrm{P} \leq 0.05$.

Table 3. Hay yields of alfalfa-grass binary mixtures in different mixture ratios $\left(\mathrm{t} \mathrm{ha}^{-1}\right)^{*}$

\begin{tabular}{|c|c|c|c|c|c|c|}
\hline \multirow{2}{*}{$\begin{array}{c}\text { Year } \\
(\mathrm{Y})\end{array}$} & \multirow{2}{*}{$\begin{array}{c}\text { Mixture } \\
(\mathrm{M})\end{array}$} & \multicolumn{3}{|c|}{ Mixture Ratio (MR) } & \multirow{2}{*}{$\begin{array}{c}\text { Mean } \\
\text { (Mixture) }\end{array}$} & \multirow{2}{*}{$\begin{array}{l}\text { Mean } \\
\text { (Year) }\end{array}$} \\
\hline & & $20 \%+80 \%$ & $30 \%+70 \%$ & $40 \%+60 \%$ & & \\
\hline \multirow{5}{*}{2010} & Alfalfa + Perennial ryegrass & 23.17 & 23.48 & 23.22 & $23.30^{\mathrm{cd}}$ & \multirow{5}{*}{$23.92^{\mathrm{B}}$} \\
\hline & Alfalfa + Orchardgrass & 25.42 & 25.30 & 26.87 & $25.86^{\mathrm{ab}}$ & \\
\hline & Alfalfa + Meadow fescue & 21.97 & 21.33 & 22.79 & $22.03^{\mathrm{d}}$ & \\
\hline & Alfalfa + Smooth bromegrass & 22.72 & 25.28 & 23.46 & $24.49^{\mathrm{bc}}$ & \\
\hline & Mean (Mixture Ratio) & 23.32 & 23.85 & 24.58 & & \\
\hline \multirow{5}{*}{2011} & Alfalfa + Perennial ryegrass & 21.49 & 22.66 & 24.90 & $23.01^{\mathrm{cd}}$ & \multirow{5}{*}{$25.60^{A}$} \\
\hline & Alfalfa + Orchardgrass & 25.13 & $26 . .0$ & 27.08 & $26.10^{\mathrm{ab}}$ & \\
\hline & Alfalfa + Meadow fescue & 26.16 & 25.89 & 26.56 & $26.20^{\mathrm{a}}$ & \\
\hline & Alfalfa + Smooth bromegrass & 25.71 & 27.28 & 28.11 & $27.07^{\mathrm{a}}$ & \\
\hline & Mean (Mixture Ratio) & 24.65 & 25.48 & 26.66 & & \\
\hline \multirow{5}{*}{$\begin{array}{c}2010 \\
- \\
2011\end{array}$} & Alfalfa + Perennial ryegrass & 22.33 & 23.07 & 24.06 & $23.15^{\mathrm{B}}$ & \multirow{5}{*}{24.76} \\
\hline & Alfalfa + Orchardgrass & 25.28 & 25.70 & 26.97 & $25.98^{\mathrm{A}}$ & \\
\hline & Alfalfa + Meadow fescue & 24.07 & 23.61 & 24.68 & $24.12^{\mathrm{B}}$ & \\
\hline & Alfalfa + Smooth bromegrass & 24.27 & 26.28 & 26.79 & $25.78^{\mathrm{A}}$ & \\
\hline & Mean (Mixture Ratio) & $23.98^{\mathrm{B}}$ & $24.67^{\mathrm{AB}}$ & $25.62^{\mathrm{A}}$ & & \\
\hline
\end{tabular}

"The means of year, mixture, mixture $\mathrm{x}$ year interaction and mixture ratio values shown in the table with the same letters are not significantly different at the $\mathrm{P} \leq 0.05$ level.

\section{Results and Discussion}

Variance analysis results of binary mixtures of alfalfa and some cool-season grasses are shown in Table 2. According to the table, the years caused significant effects at the $\mathrm{P} \leq 0.01$ level on all the properties considered in the study except the ADF ratio. On the other hand, mixtures caused significant effects at $\mathrm{P} \leq 0.01$ level on properties other than crude protein yield. While mixture ratios caused significant effects on all properties except LER at $\mathrm{P} \leq 0.01$ level, mixture $\times$ mixture ratio interaction caused statistically significant effects on NDF and ADF ratios at $\mathrm{P} \leq 0.05$ level (Table 2).

In the study, hay yields of the mixtures were determined as $23.97 \mathrm{t} \mathrm{ha}^{-1}$ in the first year and $25.60 \mathrm{t} \mathrm{ha}^{-1}$ in the second year. The average hay yield for two years was $24.76 \mathrm{t} \mathrm{ha}^{-1}$ (Table 3). The difference between years in the study may be due to the plants being stronger in the second year. The mixtures with meadow fescue and smooth bromegrass, which significantly increased the performance in the second year, and the mixtures with perennial ryegrass that lost yield in the second year, were effective on the mixture $\mathrm{x}$ year interaction of the mixture.

It can be said that the perennial ryegrass is not sufficiently adapted to the climate of the study area compared to the other grasses included in the study. On the other hand, the mixtures made with orchardgrass are at high levels in terms of yield in both years of the study. In the study performed by Singh (2007) which included orchardgrass and perennial ryegrass, it was reported that orchardgrass was the earliest blooming species among grasses in the experiment and it bloomed 12 days earlier than perennial ryegrass. In the studies, it is reported that the hay yields of alfalfa + orchardgrass mixtures changed between $22.35 \mathrm{t} \mathrm{ha}^{-1}$ and $26.60 \mathrm{t} \mathrm{ha}^{-1}$ (Amendola et al., 1997; Celiktas et al., 2003; Karakoy and Gulcan, 2007), and hay yields of alfalfa + smooth bromegrass mixtures varied between $7.86 \mathrm{t} \mathrm{ha}^{-1}$ and $26.85 \mathrm{t} \mathrm{ha}^{-1}$ (Sleugh et al., 2000; Karakoy and Gulcan, 2007; Albayrak et al., 2011).

When the hay yields are considered in terms of mixture ratio, it is seen that mixtures with $30 \%$ and $40 \%$ alfalfa are more successful in an average of two years. In general, the increased alfalfa ratio in the mixtures increased the hay yields. In this respect, it seems possible to say that the ratio of alfalfa in the mixtures is the main factor determining the hay yield. It has been stated that mixtures made with alfalfa are more efficient in terms of hay yield than sole plantings (Casler, 1988; Atis and Hatipoglu, 2008; Albayrak and 
Turk, 2013). However, it has been stated that the competitive ability of alfalfa increases in mixtures, made under irrigable conditions. For this reason, pure alfalfa can sometimes be more efficient than mixtures (Nicols and Clanton, 1985; Acikgoz, 2001).

The crude protein ratios of the mixtures in the study varied between $14.16 \%$ and $14.85 \%$ between the years, and the highest crude protein ratio was recorded in the second year of the study (Table 4). This difference between years may be due to the increase in the proportion of alfalfa in the herbage obtained from the mixtures in the second year of the study. Indeed, it has been reported by many researchers that the crude protein content of legumes is higher than that of grasses (Celen et al., 1989; Ayan et al., 1997; Sleugh et al., 2000; Weller and Cooper, 2001; Albayrak et al., 2011). Based on mixtures, the highest crude protein ratios were obtained from alfalfa + meadow fescue and alfalfa + perennial ryegrass mixtures $(14.93 \%$, $14.80 \%$ ), while the lowest crude protein ratio was determined as $13.90 \%$ from alfalfa + orchardgrass mixture.

It is thought that the main factor that causes the difference in the crude protein contents of the mixtures is the ratio of alfalfa in the mixture herbage. The determining higher crude protein ratios in the mixtures made with perennial ryegrass and meadow fescue can be considered as an indicator that the competitiveness of alfalfa in these mixtures is higher than other mixtures. Moore et al. (1990) reported that in legume + cereal mixtures, the botanical composition affects the quality of the mixture and the crude protein ratio of the mixtures varies between $12.4 \%-15.4 \%$. In previous studies, it has been reported that the crude protein content of alfalfa + smooth bromegrass binary mixtures varied between $11.6 \%$ and $18.0 \%$ (Spandl and Hesterman, 1997; Celiktas et al., 2003; Berdahl et al., 2004; Albayrak and Turk, 2013). It was emphasized that the crude protein contents of alfalfa + perennial ryegrass varied between $13.5 \%$ and $17.02 \%$ (Celiktas et al., 2003), while this ratio varied between $12.2 \%$ and $15.0 \%$ in alfalfa + orchardgrass mixtures (Celiktas et al., 2003; Majak et al., 2003). There are differences and similarities between the findings reported by the researchers and those we found. These differences may be due to ecological conditions and other treatments.
In terms of mixture ratio, crude protein contents also increased with the increasing alfalfa ratio in the study (Table 4). The highest crude protein contents were found in mixtures containing $40 \%$ alfalfa, while the lowest crude protein contents were found in $20 \%$ alfalfa plots. Consistent with our findings, it has been reported that the crude protein contents of the mixtures increased with an increasing alfalfa ratio (Majak et al., 2003; Atis and Hatipoglu, 2008).

The crude protein yields of the applications were $3.38 \mathrm{t}$ $\mathrm{h}^{-1}$ in 2010 and $3.80 \mathrm{t} \mathrm{h}^{-1}$ in 2011 , and this difference was found to be statistically significant at $\mathrm{P} \leq 0.01$ level. This difference among the years may be due to the increasing hay yield of the plots in the second year. Also increasing alfalfa proportion of the plots caused an increase in crude protein yield in the second year. The increased crude protein yield of alfalfa + smooth bromegrass and alfalfa + meadow fescue plots as opposed to alfalfa + perennial ryegrass in the second year resulted in a statistically significant effect on the mixture $x$ year interaction. When the mixtures in the study are evaluated according to mixture ratio, it is understood that the highest crude protein yields were obtained from $40 \%$ alfalfa $+60 \%$ grass plots as $3.78 \mathrm{t} \mathrm{h}^{-1}$, and the lowest values were obtained from $20 \%$ alfalfa $+80 \%$ grass plots as $3.43 \mathrm{t} \mathrm{h}^{-1}$ (Table 5). The increases in the mixture ratios of alfalfa, which is rich in crude protein content, also increased the crude protein yield of the mixtures. Atis and Hatipoglu (2008) reported in their study that increased legume ratio in binary mixtures caused an increase in crude protein yield. In this respect, our findings are similar to the researchers. In the previous studies, some researchers reported the crude protein yields of binary mixtures that $1.26 \mathrm{t} \mathrm{ha}^{-1}$ in alfalfa + smooth bromegrass, $1.82 \mathrm{t} \mathrm{ha}^{-1}$ in alfalfa orchardgrass by Ayan et al. (1997), $1.84 \mathrm{t} \mathrm{ha}^{-1}$ in alfalfa + perennial ryegrass, $2.28 \mathrm{t}$ $\mathrm{ha}^{-1}$ in alfalfa + meadow fescue by Serin et al. (1998), 0.61 $\mathrm{t} \mathrm{ha}^{-1}$ and $1.52-2.35 \mathrm{t} \mathrm{ha}^{-1}$ in alfalfa + smooth bromegrass by Basbag et al. (2007) and Yolcu et al. (2010). Some of these results are lower than our results and some are close. Different practices together with the climatic and soil conditions of the regions where the studies were carried out caused different crude protein yields.

Table 4. Crude protein contents of binary alfalfa-grass mixtures $(\%)^{*}$

\begin{tabular}{|c|c|c|c|c|c|c|}
\hline \multirow{2}{*}{$\begin{array}{l}\text { Year } \\
(Y)\end{array}$} & \multirow{2}{*}{$\begin{array}{l}\text { Mixture } \\
\text { (M) }\end{array}$} & \multicolumn{3}{|c|}{ Mixture Ratio (MR) } & \multirow{2}{*}{$\begin{array}{c}\text { Mean } \\
\text { (Mixture) }\end{array}$} & \multirow{2}{*}{$\begin{array}{l}\text { Mean } \\
\text { (Year) }\end{array}$} \\
\hline & & $20 \%+80 \%$ & $30 \%+70 \%$ & $40 \%+60 \%$ & & \\
\hline \multirow{5}{*}{2010} & Alfalfa + Perennial ryegrass & 14.58 & 14.12 & 14.87 & 14.52 & \multirow{5}{*}{$14.16^{\mathrm{B}}$} \\
\hline & Alfalfa + Orchardgrass & 13.51 & 13.66 & 13.91 & 13.70 & \\
\hline & Alfalfa + Meadow fescue & 14.31 & 14.45 & 14.80 & 14.52 & \\
\hline & Alfalfa + Smooth bromegrass & 13.60 & 13.87 & 13.40 & 13.90 & \\
\hline & Mean (Mixture Ratio) & 14.00 & 14.03 & 14.46 & & \\
\hline \multirow{5}{*}{2011} & Alfalfa + Perennial ryegrass & 15.22 & 15.41 & 15.39 & 15.34 & \multirow{5}{*}{$14.85^{\mathrm{A}}$} \\
\hline & Alfalfa + Orchardgrass & 13.59 & 14.17 & 14.57 & 14.11 & \\
\hline & Alfalfa + Meadow fescue & 14.99 & 15.05 & 15.21 & 15.09 & \\
\hline & Alfalfa + Smooth bromegrass & 14.68 & 14.74 & 15.14 & 14.86 & \\
\hline & Mean (Mixture Ratio) & 14.62 & 14.84 & 15.08 & & \\
\hline \multirow{6}{*}{$\begin{array}{c}2010 \\
- \\
2011\end{array}$} & Alfalfa + Perennial ryegrass & 14.90 & 14.77 & 15.13 & $14.93^{\mathrm{A}}$ & \multirow{5}{*}{14.51} \\
\hline & Alfalfa + Orchardgrass & 13.55 & 13.92 & 14.24 & $13.90^{\mathrm{C}}$ & \\
\hline & Alfalfa + Meadow fescue & 14.65 & 14.75 & 15.01 & $14.80^{\mathrm{A}}$ & \\
\hline & Alfalfa + Smooth bromegrass & 14.14 & 14.31 & 14.69 & $14.38^{\mathrm{B}}$ & \\
\hline & Mean (Mixture Ratio) & $14.31^{\mathrm{B}}$ & $14.44^{\mathrm{B}}$ & $14.77^{\mathrm{A}}$ & & \\
\hline & $\operatorname{LSD}(0.05)$ & \multicolumn{4}{|c|}{ Y: 0.15; M: $0.21 ;$ MR: 0.19} & \\
\hline
\end{tabular}


Table 5. Crude protein yields of the binary alfalfa-grass mixtures $\left(\mathrm{t} \mathrm{ha}^{-1}\right)^{*}$.

\begin{tabular}{|c|c|c|c|c|c|c|}
\hline \multirow{2}{*}{$\begin{array}{l}\text { Year } \\
\text { (Y) }\end{array}$} & \multirow{2}{*}{$\begin{array}{l}\text { Mixture } \\
\text { (M) }\end{array}$} & \multicolumn{3}{|c|}{ Mixture Ratio (MR) } & \multirow{2}{*}{$\begin{array}{c}\text { Mean } \\
\text { (Mixture) }\end{array}$} & \multirow{2}{*}{$\begin{array}{l}\text { Mean } \\
\text { (Year) }\end{array}$} \\
\hline & & $20 \%+80 \%$ & $30 \%+70 \%$ & $40 \%+60 \%$ & & \\
\hline \multirow{5}{*}{2010} & Alfalfa + Perennial ryegrass & 3.38 & 3.32 & 3.46 & $3.38^{\mathrm{de}}$ & $3.38^{\mathrm{B}}$ \\
\hline & Alfalfa + Orchardgrass & 3.43 & 3.46 & 3.74 & $3.54^{\mathrm{cd}}$ & \\
\hline & Alfalfa + Meadow fescue & 3.14 & 3.09 & 3.37 & $3.20^{\mathrm{e}}$ & \\
\hline & Alfalfa + Smooth bromegrass & 3.09 & 3.52 & 3.63 & $3.41^{\mathrm{de}}$ & \\
\hline & Mean (Mixture Ratio) & 3.26 & 3.34 & 3.55 & & \\
\hline \multirow{5}{*}{2011} & Alfalfa + Perennial ryegrass & 3.27 & 3.50 & 3.83 & $3.54^{\mathrm{cd}}$ & $3.80^{\mathrm{A}}$ \\
\hline & Alfalfa + Orchardgrass & 3.42 & 3.70 & 3.95 & $3.69^{\mathrm{bc}}$ & \\
\hline & Alfalfa + Meadow fescue & 3.92 & 3.90 & 4.04 & $3.95^{\mathrm{ab}}$ & \\
\hline & Alfalfa + Smooth bromegrass & 3.79 & 4.02 & 4.26 & $4.02^{\mathrm{a}}$ & \\
\hline & Mean (Mixture Ratio) & 3.59 & 3.78 & 4.02 & & \\
\hline \multirow{6}{*}{$\begin{array}{c}2010 \\
- \\
2011\end{array}$} & Alfalfa + Perennial ryegrass & 3.32 & 3.41 & 3.65 & 3.46 & 3.59 \\
\hline & Alfalfa + Orchardgrass & 3.42 & 3.58 & 3.84 & 3.61 & \\
\hline & Alfalfa + Meadow fescue & 3.53 & 3.49 & 3.71 & 3.58 & \\
\hline & Alfalfa + Smooth bromegrass & 3.44 & 3.77 & 3.94 & 3.72 & \\
\hline & Mean (Mixture Ratio) & $3.43^{\mathrm{B}}$ & $3.56^{\mathrm{B}}$ & $3.78^{\mathrm{A}}$ & & \\
\hline & $\operatorname{LSD}(0.05)$ & \multicolumn{5}{|c|}{ Y: $0.13 ; \mathrm{M} \times \mathrm{Y}$ int: $0.27 ; \mathrm{MR}: 0.16$} \\
\hline
\end{tabular}

${ }^{*}$ The means of year, mixture $\times$ year interaction and mixture ratio values shown in the table with the same letters are not significantly different at the $\mathrm{P} \leq 0.05$ level.

Table 6. NDF contents of the binary alfalfa-grass mixtures in different mixture ratios $(\%)^{*}$

\begin{tabular}{|c|c|c|c|c|c|c|}
\hline \multirow{2}{*}{$\begin{array}{l}\text { Year } \\
\text { (Y) }\end{array}$} & \multirow{2}{*}{$\begin{array}{l}\text { Mixture } \\
\text { (M) }\end{array}$} & \multicolumn{3}{|c|}{ Mixture Ratio (MR) } & \multirow{3}{*}{$\begin{array}{c}\text { Mean } \\
\text { (Mixture) } \\
48.63^{\mathrm{c}}\end{array}$} & \multirow{2}{*}{$\begin{array}{l}\text { Mean } \\
\text { (Year) }\end{array}$} \\
\hline & & $20 \%+80 \%$ & $30 \%+70 \%$ & $40 \%+60 \%$ & & \\
\hline \multirow{5}{*}{2010} & Alfalfa + Perennial ryegrass & 48.84 & 48.97 & 48.09 & & \multirow{5}{*}{$49.50^{\mathrm{A}}$} \\
\hline & Alfalfa + Orchardgrass & 51.72 & 50.87 & 49.03 & $50.14^{\mathrm{a}}$ & \\
\hline & Alfalfa + Meadow fescue & 49.96 & 49.47 & 47.83 & $49.09^{\mathrm{bc}}$ & \\
\hline & Alfalfa + Smooth bromegrass & 50.67 & 49.28 & 48.78 & $49.58^{\mathrm{b}}$ & \\
\hline & Mean (Mixture Ratio) & $50.30^{\mathrm{a}}$ & $49.65^{\mathrm{b}}$ & $48.44^{\mathrm{c}}$ & & \\
\hline \multirow{5}{*}{2011} & Alfalfa + Perennial ryegrass & 45.71 & 45.43 & 46.16 & $45.77^{\mathrm{e}}$ & \multirow{5}{*}{$47.17^{\mathrm{B}}$} \\
\hline & Alfalfa + Orchardgrass & 49.98 & 48.30 & 48.05 & $48.78^{\mathrm{c}}$ & \\
\hline & Alfalfa + Meadow fescue & 47.61 & 47.10 & 46.95 & $47.22^{\mathrm{d}}$ & \\
\hline & Alfalfa + Smooth bromegrass & 47.18 & 46.71 & 46.86 & $46.92^{\mathrm{d}}$ & \\
\hline & Mean (Mixture Ratio) & $47.62^{\mathrm{d}}$ & $47.00 \mathrm{e}$ & $46.89^{\mathrm{e}}$ & & \\
\hline \multirow{6}{*}{$\begin{array}{c}2010 \\
- \\
2011\end{array}$} & Alfalfa + Perennial ryegrass & $47.27^{\mathrm{ef}}$ & $47.20^{\mathrm{f}}$ & $47.13^{\mathrm{f}}$ & $47.20^{\mathrm{C}}$ & \multirow{5}{*}{48.34} \\
\hline & Alfalfa + Orchardgrass & $50.85^{\mathrm{a}}$ & $49.59^{\mathrm{b}}$ & $48.54^{\mathrm{cd}}$ & $49.66^{\mathrm{A}}$ & \\
\hline & Alfalfa + Meadow fescue & $48.78^{c}$ & $48.29^{\mathrm{cd}}$ & $47.39^{\mathrm{ef}}$ & $48.15^{\mathrm{B}}$ & \\
\hline & Alfalfa + Smooth bromegrass & $48.93^{\mathrm{bc}}$ & $48.00^{\text {de }}$ & $47.81^{\mathrm{d}-\mathrm{f}}$ & $48.25^{\mathrm{B}}$ & \\
\hline & Mean (Mixture Ratio) & $48.96^{\mathrm{A}}$ & $48.27^{\mathrm{B}}$ & $47.72^{\mathrm{C}}$ & & \\
\hline & LSD (0.05) $\quad$ Y: $0.31 ; \mathrm{N}$ & $4 ; \mathrm{M} \times \mathrm{Y}$ in & 63; MR: 0.3 & UR $\times Y$ int: 0.5 & $I \times$ MR int: & \\
\hline
\end{tabular}

${ }^{*}$ The means of year, mixture, mixture $\times$ year interaction, mixture ratio, mixture ratio $\times$ year interaction and mixture $\times$ mixture ratio interaction values shown in the table with the same letters are not significantly different at the $\mathrm{P} \leq 0.05$ level.

The NDF ratios of alfalfa + grass binary mixtures varied between $47.17 \%$ and $49.50 \%$ over the years (Table $6)$. The NDF ratios determined in the second year were statistically lower than the first year at the level of $\mathrm{P} \leq 0.01$. It is possible to explain this situation with the rate of alfalfa that increases the second year dominance in the mixture plots. Because the NDF ratios of legumes are lower than those of grasses. On this topic, Moore et al. (1990) reported that the botanical composition significantly affects the yield and quality in legume + grass mixtures. Similar to our findings, some researchers reported that NDF rates decreased with the following years, and the reason for this situation was the increased legume ratios in the botanical composition of the mixtures (Dhima et al., 2007; Atis and Hatipoglu, 2008).

The NDF ratios of the mixtures varied between $47.20 \%$ and $49.66 \%$ on the average of the two years, while the lowest NDF ratio was found in alfalfa + perennial ryegrass mixtures, and the highest NDF ratio was found in alfalfa + orchardgrass mixtures. The dominance of orchardgrass in the mixture plots compared to other grass has higher NDF ratios, whereas the low performance of perennial ryegrass in mixtures caused the NDF rates to be lower. In the second year of the study, the increases in alfalfa competition in perennial ryegrass and smooth bromegrass plots, in addition to the increased alfalfa ratios in the second year, caused the year $\times$ mixture interaction to be found statistically significant (Table 6).

When the NDF contents are considered in terms of mixture ratios, it can be seen that the NDF ratios decrease in parallel with the increasing alfalfa ratio in the mixture ratio. In terms of mixture ratios, the lowest NDF ratios were detected as $47.72 \%$ in $40 \%$ alfalfa $+60 \%$ grass plots. In the average of the two years, the NDF ratios of the plots showed significant differences at $\mathrm{P} \leq 0.01$ level in terms of mixture $\times$ mixture ratio interaction and the values varied between $50.85 \%$ and $47.13 \%$. In this context, the highest NDF ratio was determined in the mixture of $20 \%$ alfalfa + $80 \%$ orchardgrass, while the lowest NDF ratio was determined in $40 \%$ alfalfa $+60 \%$ perennial ryegrass plots. 
This may be because the perennial ryegrass performed poorly compared to other grass species in the trial, together with the increased alfalfa ratio in mixtures, as well as the superior performance of the orchardgrass.

In previous studies, it has been reported that the NDF contents of alfalfa + smooth bromegrass mixtures vary between 50.19\% - 62.40\% (Spandl and Hesterman, 1997; Berdahl et al., 2004; Albayrak et al., 2011). However, Kunelius et al. (2006) stated that NDF contents were $42.1 \%$ in alfalfa + timothy grass + perennial ryegrass and $43.4 \%$ in alfalfa + timothy + meadow fescue. The NDF contents determined in this study were generally lower than the values reported by the researchers. These differences in results may be due to botanical composition, harvest time, and ecological factors at trial sites.

Average values of $\mathrm{ADF}$ contents of alfalfa-grass mixtures in different mixture ratios are shown in Table 7. On the average of two years, ADF contents varied between $32.70 \%$ and $33.32 \%$ based on mixtures, and the lowest ADF contents were found in alfalfa + perennial ryegrass mixtures. However, other mixtures were found to be statistically insignificant from each other. ADF contents varied between $32.72 \%$ and $33.25 \%$, the lowest ADF contents were determined in $20 \%$ alfalfa $+80 \%$ grass mixtures in terms of mixture ratios. It is known that ADF contents of grasses are higher than legumes. However, ADF content is decreasing despite the increasing rate of grass in the study. This situation may be since, in mixed plantings, grasses cannot achieve the stem development sufficiently due to the shading effect of the alfalfa. On the other hand, the fact that alfalfa had more branching and stem development at low-density seeding rates may have increased ADF contents. In previous studies on alfalfa + grass mixtures, ADF contents were found $39.5 \%$ in alfalfa + smooth bromegrass (Spandl and Hesterman, 1997), 28\% in alfalfa + timothy grass + perennial ryegrass, $29 \%$ in alfalfa + timothy grass + meadow fescue (Kunelius et al., 2006) and $37.05 \%$ in alfalfa + smooth bromegrass (Albayrak et al., 2011). Our results were found to be lower than the values expressed by the researchers. Considering that the differences in the ecological conditions in the studies as well as the differences in the experimental factors can significantly affect the quality of the herbage, the difference between the research results can be considered as a natural result.

The land equivalent ratio is a value calculated to reveal the possible advantages and disadvantages of the mixtures in the study against pure sowings. It refers to the amount of area required to obtain the yields of the mixture systems from the unit area, even when the plants are grown alone (Kizilsimsek and Erol, 2000). In the study, while LER values were determined as 1.33 in 2010, it was determined as 1.41 in 2011 (Table 8). The reason for this difference that emerged between years can be demonstrated that the grasses in the mixtures benefit more from the nitrogen fixed by the alfalfa the second year, as well as the shade effect of the alfalfa that protects the $\mathrm{C}_{3}$ character grass from high temperatures. Cinar and Hatipoglu (2014) reported that the LER values in alfalfa and some perennial hot season grass mixtures varied between 1.05 and 1.57 years, and the LER values in the second and third years were higher than the first year. This result supports our findings.

Among the applications, the highest LER values were determined as 1.53 and 1.50 in alfalfa + perennial ryegrass and alfalfa + smooth bromegrass mixtures, respectively. According to this result, it is possible to say that perennial ryegrass and smooth bromegrass are more positively affected by cultivation together with alfalfa than orchardgrass and meadow fescue. In previous studies, LER values of the mixtures were determined 1.28 in alfalfa + smooth bromegrass by Gokkus et al. (1999). Cinar and Hatipoglu (2014) stated that the LER values varied between 1.19-1.63 in alfalfa and some perennial hot season grasses mixtures. LER values of all mixtures in the study were found to be greater than 1 . In other words, mixtures are more advantageous than pure plantings. In terms of these results, our results are in agreement with the values reported by the researchers. It has also been emphasized in previous studies that planting in the mixture is more advantageous than pure sowings (Albayrak et al., 2011; Kavut et al., 2014; Atis and Acikalin, 2020).

Table 7. ADF contents of the binary alfalfa-grass mixtures in different mixture ratio (\%)*

\begin{tabular}{|c|c|c|c|c|c|c|}
\hline \multirow{2}{*}{$\begin{array}{l}\text { Year } \\
(\mathrm{Y})\end{array}$} & \multirow{2}{*}{$\begin{array}{l}\text { Mixture } \\
(\mathrm{M})\end{array}$} & \multicolumn{3}{|c|}{ Mixture Ratio (MR) } & \multirow{2}{*}{$\begin{array}{l}\text { Mean } \\
\text { (Mixture) }\end{array}$} & \multirow{2}{*}{$\begin{array}{l}\text { Mean } \\
\text { (Year) }\end{array}$} \\
\hline & & $20 \%+80 \%$ & $30 \%+70 \%$ & $40 \%+60 \%$ & & \\
\hline \multirow{5}{*}{2010} & Alfalfa + Perennial ryegrass & 32.31 & 32.94 & 33.21 & $32.82^{\mathrm{cd}}$ & \multirow{5}{*}{33.03} \\
\hline & Alfalfa + Orchardgrass & 32.80 & 32.82 & 33.13 & $32.91^{\mathrm{cd}}$ & \\
\hline & Alfalfa + Meadow fescue & 32.53 & 33.08 & 32.81 & $32.81^{\mathrm{cd}}$ & \\
\hline & Alfalfa + Smooth bromegrass & 33.19 & 33.89 & 33.70 & $33.59^{\mathrm{a}}$ & \\
\hline & Mean (Mixture Ratio) & 32.71 & 33.18 & 33.21 & & \\
\hline \multirow{5}{*}{2011} & Alfalfa + Perennial ryegrass & 32.00 & 32.86 & 32.90 & $32.59^{\mathrm{d}}$ & \multirow{5}{*}{33.09} \\
\hline & Alfalfa + Orchardgrass & 32.73 & 33.09 & 33.90 & $33.24^{\mathrm{a}-\mathrm{c}}$ & \\
\hline & Alfalfa + Meadow fescue & 33.43 & 34.14 & 32.89 & $33.49^{\mathrm{ab}}$ & \\
\hline & Alfalfa + Smooth bromegrass & 32.81 & 33.17 & 33.16 & $33.05^{\mathrm{b}-\mathrm{d}}$ & \\
\hline & Mean (Mixture Ratio) & 32.74 & 33.32 & 33.21 & & \\
\hline \multirow{6}{*}{$\begin{array}{c}2010 \\
- \\
2011\end{array}$} & Alfalfa + Perennial ryegrass & $32.16^{\mathrm{e}}$ & $32.90^{\mathrm{cd}}$ & $33.06^{\mathrm{a}-\mathrm{d}}$ & $32.70^{\mathrm{B}}$ & \multirow{5}{*}{33.06} \\
\hline & Alfalfa + Orchardgrass & $32.76^{\mathrm{d}}$ & $32.95^{\mathrm{cd}}$ & $33.52^{\mathrm{ab}}$ & $33.08^{\mathrm{A}}$ & \\
\hline & Alfalfa + Meadow fescue & $32.98^{\mathrm{b}-\mathrm{d}}$ & $33.61^{\mathrm{a}}$ & $32.85^{\mathrm{d}}$ & $33.15^{\mathrm{A}}$ & \\
\hline & Alfalfa + Smooth bromegrass & $33.00^{\mathrm{b}-\mathrm{d}}$ & $33.53^{\mathrm{ab}}$ & $33.43^{\mathrm{a}-\mathrm{c}}$ & $33.32^{\mathrm{A}}$ & \\
\hline & Mean (Mixture Ratio) & $32.72^{\mathrm{B}}$ & $33.25^{\mathrm{A}}$ & $33.21^{\mathrm{A}}$ & & \\
\hline & $\operatorname{LSD}(0.05)$ & $0.32, \mathrm{M} \times$ & nt: $0.46, \mathrm{MR}$ & $28, \mathrm{M} \times \mathrm{MR}$ & 0.56 & \\
\hline
\end{tabular}

${ }^{*}$ The means of mixture, mixture $\mathrm{x}$ year interaction, mixture ratio and mixture $\mathrm{x}$ mixture ratio interaction values shown in the table with the same letters are not significantly different at the $\mathrm{P} \leq 0.05$ level. 
Table 8. Land equivalent ratio (LER) of the binary alfalfa-grass mixtures*

\begin{tabular}{|c|c|c|c|c|c|c|}
\hline \multirow{2}{*}{$\begin{array}{l}\text { Year } \\
(\mathrm{Y})\end{array}$} & \multirow{2}{*}{$\begin{array}{c}\text { Mixture } \\
(\mathrm{M})\end{array}$} & \multicolumn{3}{|c|}{ Mixture Ratio (MR) } & \multirow{2}{*}{$\begin{array}{c}\text { Mean } \\
\text { (Mixture) }\end{array}$} & \multirow{2}{*}{$\begin{array}{l}\text { Mean } \\
\text { (Year) }\end{array}$} \\
\hline & & $20 \%+80 \%$ & $30 \%+70 \%$ & $40 \%+60 \%$ & & \\
\hline \multirow{5}{*}{2010} & Alfalfa + Perennial ryegrass & 1.51 & 1.49 & 1.30 & $1.44^{\mathrm{bc}}$ & \multirow{5}{*}{$1.33^{\mathrm{B}}$} \\
\hline & Alfalfa + Orchardgrass & 1.35 & 1.27 & 1.27 & $1.30^{\mathrm{d}}$ & \\
\hline & Alfalfa + Meadow fescue & 1.19 & 1.12 & 1.13 & $1.14^{\mathrm{e}}$ & \\
\hline & Alfalfa + Smooth bromegrass & 1.40 & 1.48 & 1.40 & $1.43^{c}$ & \\
\hline & Mean (Mixture Ratio) & 1.36 & 1.34 & 1.28 & & \\
\hline \multirow{5}{*}{2011} & Alfalfa + Perennial ryegrass & 1.69 & 1.64 & 1.57 & $1.63^{\mathrm{a}}$ & \multirow{5}{*}{$1.41^{\mathrm{A}}$} \\
\hline & Alfalfa + Orchardgrass & 1.27 & 1.22 & 1.17 & $1.22^{\mathrm{de}}$ & \\
\hline & Alfalfa + Meadow fescue & 1.29 & 1.21 & 1.19 & $1.23^{\mathrm{de}}$ & \\
\hline & Alfalfa + Smooth bromegrass & 1.59 & 1.58 & 1.53 & $1.57^{\mathrm{ab}}$ & \\
\hline & Mean (Mixture Ratio) & 1.46 & 1.41 & 1.36 & & \\
\hline \multirow{5}{*}{$\begin{array}{c}2010 \\
- \\
2011\end{array}$} & Alfalfa + Perennial ryegrass & 1.60 & 1.57 & 1.43 & $1.53^{\mathrm{A}}$ & \multirow{5}{*}{1.37} \\
\hline & Alfalfa + Orchardgrass & 1.31 & 1.24 & 1.22 & $1.26^{\mathrm{B}}$ & \\
\hline & Alfalfa + Meadow fescue & 1.24 & 1.16 & 1.16 & $1.19^{\mathrm{B}}$ & \\
\hline & Alfalfa + Smooth bromegrass & 1.50 & 1.53 & 1.47 & $1.50^{\mathrm{A}}$ & \\
\hline & Mean (Mixture Ratio) & 1.41 & 1.38 & 1.32 & & \\
\hline
\end{tabular}

${ }^{*}$ The means of year, mixture and mixture $\times$ year interaction values shown in the table with the same letters are not significantly different at the $\mathrm{P} \leq 0.05$ level.

Table 9. Grass ratios in the total hay yield of binary alfalfa-grass mixtures $(\%) *$

\begin{tabular}{|c|c|c|c|c|c|c|}
\hline \multirow{2}{*}{$\begin{array}{l}\text { Year } \\
(Y)\end{array}$} & \multirow{2}{*}{$\begin{array}{l}\text { Mixture } \\
\text { (M) }\end{array}$} & \multicolumn{3}{|c|}{ Mixture Ratio (MR) } & \multirow{2}{*}{$\begin{array}{c}\text { Mean } \\
\text { (Mixture) }\end{array}$} & \multirow{2}{*}{$\begin{array}{l}\text { Mean } \\
\text { (Year) }\end{array}$} \\
\hline & & $20 \%+80 \%$ & $30 \%+70 \%$ & $40 \%+60 \%$ & & \\
\hline \multirow{5}{*}{2010} & Alfalfa + Perennial ryegrass & 35.76 & 33.34 & 22.01 & $30.37^{\mathrm{a}}$ & \multirow{5}{*}{$28.67^{\mathrm{A}}$} \\
\hline & Alfalfa + Orchardgrass & 40.05 & 30.02 & 19.82 & $29.96^{\mathrm{a}}$ & \\
\hline & Alfalfa + Meadow fescue & 29.06 & 25.08 & 17.15 & $23.76^{\mathrm{b}}$ & \\
\hline & Alfalfa + Smooth bromegrass & 36.62 & 30.81 & 24.28 & $30.57^{\mathrm{a}}$ & \\
\hline & Mean (Mixture Ratio) & $35.37^{\mathrm{a}}$ & $29.81^{\mathrm{b}}$ & $20.81^{\mathrm{c}}$ & & \\
\hline \multirow{5}{*}{2011} & Alfalfa + Perennial ryegrass & 12.33 & 10.43 & 7.88 & $10.18^{\mathrm{e}}$ & \multirow{5}{*}{$17.22^{\mathrm{B}}$} \\
\hline & Alfalfa + Orchardgrass & 29.69 & 21.77 & 15.36 & $22.27^{\mathrm{bc}}$ & \\
\hline & Alfalfa + Meadow fescue & 19.73 & 15.59 & 12.82 & $16.05^{\mathrm{d}}$ & \\
\hline & Alfalfa + Smooth bromegrass & 24.00 & 20.15 & 17.00 & $20.38^{\mathrm{c}}$ & \\
\hline & Mean (Mixture Ratio) & $21.41^{\mathrm{c}}$ & $16.99^{\mathrm{d}}$ & $13.26^{\mathrm{e}}$ & & \\
\hline \multirow{6}{*}{$\begin{array}{c}2010 \\
- \\
2011\end{array}$} & Alfalfa + Perennial ryegrass & $24.00^{\mathrm{cd}}$ & $21.89^{\mathrm{de}}$ & $14.94^{\mathrm{g}}$ & $20.28^{\mathrm{B}}$ & \multirow{5}{*}{22.95} \\
\hline & Alfalfa + Orchardgrass & $34.87^{\mathrm{a}}$ & $25.89^{c}$ & $17.59^{\mathrm{fg}}$ & $26.12^{\mathrm{A}}$ & \\
\hline & Alfalfa + Meadow fescue & $24.39^{\mathrm{cd}}$ & $20.34^{\text {ef }}$ & $14.99^{\mathrm{g}}$ & $19.91^{\mathrm{B}}$ & \\
\hline & Alfalfa + Smooth bromegrass & $30.31^{\mathrm{b}}$ & $25.48^{\mathrm{c}}$ & $20.64^{\mathrm{e}}$ & $25.48^{\mathrm{A}}$ & \\
\hline & Mean (Mixture Ratio) & $28.39^{\mathrm{A}}$ & $23.40^{\mathrm{B}}$ & $17.04^{\mathrm{C}}$ & & \\
\hline & $\begin{array}{ll}\operatorname{LSD}(0.05) & \mathrm{Y}: 1.16 ; \mathrm{N} \\
\end{array}$ & $53 ; \mathrm{M} \times \mathrm{Y} \mathrm{i}$ & 31; MR: 1.41 & $\mathrm{IR} \times \mathrm{Y}$ int: 2 & $M \times M R$ in & \\
\hline
\end{tabular}

${ }^{*}$ The means of year, mixture, mixture $\times$ year interaction, mixture ratio, mixture ratio $\times$ year interaction and mixture $\times$ mixture ratio interaction values shown in the table with the same letters are not significantly different at the $\mathrm{P} \leq 0.05$ level.

The grass ratio values in the hay have shown in Table 9. Changing the grasses ratio based on the cuttings can be seen in Table 10. The rate of grasses in the hay was $28.67 \%$ in 2010 and $17.22 \%$ in 2011. In the second year, while the alfalfa ratios in hay yield increased, the grasses ratios decreased. These differences among the years may be since the alfalfa, which strengthened in the second year, shaded the grasses. Although the irrigation was carried out regularly in the study, the grasses could not be adapting to the cutting frequency of alfalfa in both years except for the first cuttings. Therefore, caused the grass ratio to remain low over time (Tables 9, 10). Similar to the findings in the study, Albayrak (2003) and Erol (2007) in the alfalfa + smooth bromegrass mixtures, Avci (2000), in alfalfa mixtures of perennial ryegrass and tall fescue, Atis and Hatipoglu (2008), in white clover and orchardgrass mixture, reported that the rate of grasses in mixtures reduced with the advancing years.
When the ratios of grasses in hay yield are examining in terms of grass species that mixed with alfalfa, it can observe that the highest ratios of grass in hay determined in mixtures made with orchardgrass and smooth bromegrass. Accordingly, it possible to say that orchardgrass and smooth bromegrass are the best competing grass species with alfalfa. Orchardgrass had rapid development in the spring and, smooth bromegrass has rhizomes. Therefore, these grasses maintained their positions in the second years' ratios compared to the other grasses. On the other hand, the contribution of perennial ryegrass and meadow fescue to hay yield remained at low levels in the second year. This situation caused the year $\mathrm{x}$ mixture interaction to be significant. In this regard, Altin and Gokkus (1988) reported that the most suitable mixtures for long-term hay production are alfalfa + smooth bromegrass mixtures. Avci (2000) stated that the perennial ryegrass ratio in alfalfa + perennial grass mixtures is $47 \%$ 
on the average of three years. Albayrak (2003) reported that the rate of smooth bromegrass in alfalfa + smooth bromegrass mixtures is $24.93 \%$ on the average of two years, and Yavuz (2011) stated that the grass ratio varied between $27.51-35.73 \%$ in alfalfa smooth bromegrass mixtures and $27.11-29.94 \%$ in mixtures of alfalfa + orchardgrass. The values determined in this study are in harmony with the values reported by Albayrak (2003) and Yavuz (2011), while lower than the values reported by Avci (2000).

When the mixtures compare according to the sowing rates in the study, the ratio of grass in the hay increased in parallel with the increased sowing ratio. The highest ratios of grasses in the hay yield were determined in mixtures of $20 \%$ alfalfa $+80 \%$ grass, followed by $70 \%$ and $60 \%$ grass, respectively. But in all mixes, the sowing ratio of the grass could not be reached obtained in the harvest. Atis and Hatipoglu (2008) reported that the rate of grasses in hay increased in parallel with the increasing rate of grasses in white clover + orchardgrass and white clover + perennial ryegrass mixtures, and determined the grass ratio in the hay was between $19.9 \%$ - $47.9 \%$, and $38.8 \%$ - $41.5 \%$, respectively. Also, Erol (2007) determined that planting rates in alfalfa + smooth bromegrass mixtures do not reflect harvest, and grass ratios range from $9.3 \%$ to $47.2 \%$.

Table 10. Grass ratios of the hay yield according to the cuttings in average of two years $(\%)^{*}$

\begin{tabular}{|c|c|c|c|c|}
\hline \multirow{2}{*}{ Mixtures (M) } & \multicolumn{4}{|c|}{ Cuttings $(\mathrm{C})$} \\
\hline & $1^{\text {st }}$ & $2^{\text {nd }}$ & $3^{\text {rd }}$ & $4^{\text {th }}$ \\
\hline $20 \%$ Alfalfa $+80 \%$ Perennial ryegrass & $39.96^{\mathrm{d}-\mathrm{f}}$ & $12.88^{\mathrm{o}-\mathrm{s}}$ & $12.53^{\mathrm{o}-\mathrm{t}}$ & $10.19^{\mathrm{r}-\mathrm{w}}$ \\
\hline $30 \%$ Alfalfa $+70 \%$ Perennial ryegrass & $39.22 \mathrm{e}^{\mathrm{f}}$ & $9.66^{\mathrm{s}-\mathrm{w}}$ & $10.13^{\mathrm{r}-\mathrm{w}}$ & $6.85^{\mathrm{u}-\mathrm{w}}$ \\
\hline $40 \%$ Alfalfa $+60 \%$ Perennial ryegrass & $28.79^{\mathrm{hi}}$ & $6.59^{\mathrm{vw}}$ & $9.41^{\mathrm{s}-\mathrm{w}}$ & $5.96^{\mathrm{w}}$ \\
\hline $20 \%$ Alfalfa $+80 \%$ Orchardgrass & $53.61^{\mathrm{a}}$ & $28.47^{\mathrm{hi}}$ & $21.76^{\mathrm{jk}}$ & $19.90^{\mathrm{k}-\mathrm{m}}$ \\
\hline $30 \%$ Alfalfa $+70 \%$ Orchardgrass & $43.67^{\mathrm{c}-\mathrm{e}}$ & $16.28^{\mathrm{m}-\mathrm{p}}$ & $17.8^{9 \mathrm{k}-\mathrm{n}}$ & $16.03^{\mathrm{m}-\mathrm{q}}$ \\
\hline $40 \%$ Alfalfa $+60 \%$ Orchardgrass & $29.52^{\mathrm{hi}}$ & $13.35^{\mathrm{n}-\mathrm{s}}$ & $11.23^{\mathrm{r}-\mathrm{v}}$ & $10.64^{\mathrm{r}-\mathrm{v}}$ \\
\hline $20 \%$ Alfalfa $+80 \%$ Meadow fescue & $48.94^{\mathrm{ab}}$ & $13.51^{\mathrm{n}-\mathrm{s}}$ & $11.75^{\mathrm{p}-\mathrm{t}}$ & $10.02^{\mathrm{r}-\mathrm{w}}$ \\
\hline $30 \%$ Alfalfa $+70 \%$ Meadow fescue & $39.98^{\mathrm{d}-\mathrm{f}}$ & $11.53^{\mathrm{q}-\mathrm{t}}$ & $10.15^{\mathrm{r}-\mathrm{w}}$ & $9.57^{\mathrm{s}-\mathrm{w}}$ \\
\hline $40 \%$ Alfalfa $+60 \%$ Meadow fescue & $32.56^{\mathrm{gh}}$ & $8.07^{t-w}$ & $7.96^{\mathrm{t}-\mathrm{w}}$ & $9.06^{\mathrm{s}-\mathrm{w}}$ \\
\hline $20 \%$ Alfalfa $+80 \%$ Smooth bromegrass & $46.71^{\mathrm{bc}}$ & $26.20^{\mathrm{ij}}$ & $20.98^{\mathrm{kl}}$ & $14.69^{\mathrm{n}-\mathrm{r}}$ \\
\hline $30 \%$ Alfalfa $+70 \%$ Smooth bromegrass & $44.37^{\mathrm{b}-\mathrm{d}}$ & $19.76^{\mathrm{k}-\mathrm{m}}$ & $16.70^{1-o}$ & $11.99^{\mathrm{p}-\mathrm{t}}$ \\
\hline $40 \%$ Alfalfa $+60 \%$ Smooth bromegrass & $36.69^{\mathrm{fg}}$ & $15.99^{\mathrm{m}-\mathrm{q}}$ & $11.38^{\mathrm{q}-\mathrm{u}}$ & $9.34^{\mathrm{s}-\mathrm{w}}$ \\
\hline Mean (Cuttings) & $40.33^{\mathrm{A}}$ & $15.19^{\mathrm{B}}$ & $13.49^{\mathrm{C}}$ & $11.19^{\mathrm{D}}$ \\
\hline 2010 & $51.25^{\mathrm{a}}$ & $14.35^{\mathrm{c}}$ & $11.51^{\mathrm{d}}$ & $14.20^{\mathrm{c}}$ \\
\hline 2011 & $29.42^{\mathrm{b}}$ & $16.03^{\mathrm{c}}$ & $15.46^{\mathrm{c}}$ & $8.18^{\mathrm{e}}$ \\
\hline LSD (0.05) & $\mathrm{M} \times \mathrm{C}$ int: $4.64^{* *}$ & Cuttings: $1.35^{* *}$ & $\mathrm{C} \times \mathrm{Y}$ int & \\
\hline $\mathrm{CV}(\%)$ & 20.47 & & & \\
\hline
\end{tabular}

*The means of $\mathrm{M} \times \mathrm{C}$ interaction, Cuttings and Year $(\mathrm{Y}) \times$ cutting interaction values shown in the table with the same letters are not significantly different at the $\mathrm{P} \leq 0.05$ level. ${ }^{* *} \mathrm{P} \leq 0.01 ; \mathrm{CV}$, coefficient of variation.

According to the cuttings, the highest grass ratio was determined as $53.61 \%$ in the mixture of $20 \%$ alfalfa $+80 \%$ orchardgrass, in the first cutting on average of the years. This mixture and $20 \%$ alfalfa $+80 \%$ meadow fescue mixture were included in the same statistical group. With the advancing cuttings, the share of grasses in hay yield decreased significantly. However, these decreases were more pronounced especially in mixtures formed with perennial ryegrass. This situation caused the importance of the mixture $\mathrm{x}$ year interaction. Although mixtures made with orchardgrass and smooth bromegrass show a more stable structure than mixtures made with perennial ryegrass and meadow fescue, alfalfa was dominant in all mixtures (Table 10). Many researchers (Spandl and Hesterman, 1997; Avci, 2000; Berdahl et al., 2004; Yavuz and Karadag, 2016) emphasized that alfalfa became the dominant species in mixtures over time.

Based on the cuttings, the highest grass ratios were obtained from the first cuttings, while the lowest rates were in the fourth cuttings. While the grass rate in the first cuttings was $40.33 \%$, this rate decreased to $11.19 \%$ in the fourth cuttings. The fact that the grasses in the study consist of plants with $\mathrm{C} 3$ photosynthetic pathways can show as the reason for this situation. Thus it has been reported that with the increase of temperatures in areas where the Mediterranean climate observed, the grass yield of cool- season forage crops generally decreases (Langer, 1994), and $\mathrm{C} 3$ plants present in the pastures disappear from the environment as the temperatures exceed $25^{\circ} \mathrm{C}$ (Gundel et al., 2014).

\section{Conclusions}

According to the results, the superiority of alfalfa in the mixtures was felt in many parameters, specifically hay and crude protein yield. Especially in perennial ryegrass, with the effect of high temperatures, significant yield losses occurred in the second year in addition to the contribution of perennial ryegrass to the mixture yields was clearly low. Orchardgrass and smooth bromegrass are the most compatible species with alfalfa in terms of the development stage in the harvest. Nevertheless, not all of the grasses in the experiment were able to adapt to the cutting frequency of the alfalfa. On the other hand, the LER values of all mixtures were found over 1 . In other words, all mixes were found more advantageous than sole plantings. Increasing the alfalfa sowing ratio in the mixtures positively affected all quality characteristics such as crude protein content, $\mathrm{NDF}$, and ADF. It was concluded that orchardgrass and smooth bromegrass binary mixtures with alfalfa produced high yield and quality hay and that the mixture should contain $40 \%$ alfalfa and $60 \%$ grass. 


\section{Acknowledgements}

The authors are grateful to Suleyman Demirel University Coordinationship of Scientific Research Projects for financial supports (Project No: 2275-D-10). This article is a part of the first author's (OY) Ph.D. thesis.

\section{References}

Acikgoz E. 2001. Forage Crops. Uludag University Faculty of Agriculture Publications ( $3^{\text {rd }}$ Edition), Pub. No: 58, Bursa (in Turkish).

Albayrak S. 2003. An Investigation on the Establishment of Artificial Pasture in Ankara Ecological Conditions. Graduate School of Natural and Applied Sci., Department of Field Crops. (PhD Thesis) 167 p, Ankara (in Turkish).

Albayrak S, Turk M, Yuksel O, Yilmaz M. 2011. Forage yield and the quality of perennial legume-grass mixtures under rainfed conditions. Not Bot Hort Agr. Cluj, 39(1):114-118.

Albayrak S, Turk M. 2013. Changes in the forage yield and quality of legume-grass mixtures throughout a vegetation period. Turk Journal of Agriculture and Forestry, 37: 139147.

Altin M, Gokkus A. 1988. A research on hay yields of some forage crops and their mixtures in different sowing types in Erzurum irrigated conditions. J. of Nature Agric. and For., 12: 24-36 (in Turkish).

Amendola MRD, Alvarez C, Ramirez J. 1997. Grass-Legume Mixtures under Grazing. Proceeding of the XVIII International Grassland Congress, Canada, pp.121-122.

Anonymous, 2010. Ankom Technicology, Analytical Procedures. Web site, http://www.ankom.com/analytical-procedures.aspx (Accessed July 26. 2012).

Atis I, Hatipoglu R. 2008. Research on the determination of proper perennial forage grasses and their mixture rates for the pasture mixtures with white clover (Trifolium repens L.) under Irrigated conditions of Cukurova. Cukurova Uni., Journal of Institute of Natural and Appl. Sci., 18(2): 84-93 (in Turkish).

Atis I, Acikalin S. 2020. Yield, quality and competition properties of grass pea and wheat grown as pure and binary mixture in different plant densities. Turk Journal of Field Crops 25(1): 18-25.

Avc1 M. 2000. Determining Suitable Mixtures of Cool-Season Perennial Grasses and Legumes for Establishment of ShortTerm Pasture in Cukurova Region. Department of Field Crops, Inst. of Natural and Applied Sci. (PhD Thesis) 113 p, Adana (in Turkish).

Ayan I, Acar Z, Manga I, Ozyazici M. 1997. A Research on the Growing Possibilities of Some Perennial Fodder Plant Mixtures without Irrigation in Uneven and Outcropped Lands in Samsun Ecological Conditions. II.Turkey Field Crop Congress, 22-25 September, Samsun, pp. 386-390 (in Turkish).

Basbag M, Kalkanli MB, Gul I, Saruhan V. 2007. Performance of grass-legume mixtures under irrigation in the southeastern Anatolia region of Turkey. Journal of Biological Sciences, 7 (7): 1254-1257.

Berdahl JD, Karn JF, Hendrickson JR. 2004. Nutritive quality of cool-season grass monocultures and binary grass-alfalfa mixtures at late harvest. Agr. Journal, 96: 951-955.

Casler MD. 1988. Performance of orchardgrass, smooth bromegrass, and ryegrass in binary mixtures with alfalfa. Agronomy Journal, 80: 509-514.

Coulman BE. 1987. Yield and composition of monocultures bromegrass, orchardgrass, timothy. Can. J. Plant Sci. 67: 203214.
Cecen S, Erdurmus C, Oten M. 2005. Determination of Suitable Forage Plants that can be Used in Artificial Pasture Areas in Antalya Conditions. VI. Turkey Field Crop Congress, 5-9 September 2005. Volume II, Antalya, pp. 386-390 (in Turkish).

Celiktas N, Kokten K, Tukel T, Hatipoglu R, Polat T, Kutlu HR, Gorgulu M. 2003. A Research on the Determination of Perennial Grass + Legume Mixtures Suitable for Cutting and Grazing under GAP and Cukurova Conditions. V. Turkey Field Crop Congress, 7-13 October 2003. Diyarbakir, pp. 6469 (in Turkish).

Celen AE, Genckan MS, Soya H, Tosun M. 1989. The effect of different cutting rows on the yield and some other characters of persian clover (Trifolium resupinatum $\mathrm{L}$ ) annual ryegrass (Lolium multiflorum var westerwoldicum) mixtures. Journal of Agriculture Faculty of Ege University, Vol. 26: 83-92 (in Turkish).

Cinar S, Hatipoglu R. 2014. Forage yield and botanical composition of mixtures of some perennial warm season grasses with alfalfa (Medicago sativa L.) under Mediterranean conditions. Turkish Journal of Field Crops 19(1): 13-18.

Dhima KV, Lithourgidis AS, Vasilakoglou IB, Dordas CA. 2007. Competition indices of common vetch and cereal intercops in two seeding ratio. Field Crops Res. 100: 249-256.

Erol T. 2007. Effects of Gypsum Apllication and Mixture Rates on Forage Yields of Alfalfa (Medicago sativa L.) and Smooth brome (Bromus inermis Leyss). Graduate School of Natural and Applied Sci., Dep. of Field Crops. (PhD Thesis) 89 p, Ankara (in Turkish).

Gokkus A, Koc A, Serin Y, Comakli B, Tan M, Kantar F. 1999. Hay yield and nitrogen harvest in smoot bromegrass mixtures with alfalfa and red clover in relation to nitrogen application. European Journal of Agronomy, 10: 145-151.

Gundel FD, Karadag Y, Cinar S. 2014. A research on yield, quality and adaptation of some warm season perennial legumes under Çukurova ecological conditions. Journal of Agricultural Faculty of Gaziosmanpasa University, 31 (3), 10-19 (in Turkish).

Kacar B, Inal A. 2008. Plant Analysis. Nobel Press Lim. Company, Publications, Publication No: 1241; Science: 63, (First Edition) Ankara (in Turkish).

Karakoy T, Gulcan H. 2007. A Study on the Effect of Alfalfa Mixtures (Medicago sativa L.) with Different Proportions of Orchardgrass (Dactylis glomerata L.) and Smooth Bromegrass (Bromus inermis L.) on Yield and Yield-Related Parameters in Cukurova Conditions. VII. Turkey Field Crop Congress, 25-27 June 2007. Erzurum, pp. 332-336 (in Turkish).

Kavut YT, Geren H, Soya H, Avcioglu R, Kir B. 2014. Effects of rate mixture and time of harvest on the winter second crop performances of mixtures of some annual legumes and Italian ryegrass. Journal of Agric. Faculty of Ege University, 51(3): 279-288 (in Turkish).

Kizilsimsek M, Erol A. 2000. Land equivalent rate, inter species competition and nutrient supplementation index in intercropping of forage crops. Journal of Science and Engineering, 3(1): 14-22. (in Turkish).

Kunelius HT, Durr GH, McRae KB, Fillmore SAE. 2006. Performance of timothy-based grass/legume mixtures in cold winter region. J. Agronomy \& Crop Science 192: 159-167.

Langer RHM. 1994. Pasture Plant, (R.H.M. Langer ed.), Pastures, Oxford University Press. Auckland, p: 39-74

Majak W, Garland GJ, Lysyk TJ. 2003. The effect of herbage mixtures of alfalfa and orchardgrass on the incidence of bloat in cattle. Can. J. Anim. Sci., 83: 827-829. 
Moore KJ, Roberts CA, Frittz OJ. 1990. Indirect estimation of botanical composition of alfalfa-smooth bromegrass mixtures. Agronomy Journal, 82: 287-290.

Nicols JT, Clanton DC. 1985. Irrigated Pastures (E. Heath, F. Barnes, S. Metcalfe eds.), Forages. Iowa State University Press Iowa, pp. 507-516.

Serin Y, Gokkus A, Tan M, Comakli B, Koc A. 1998. Determination of suitable forage crop species and their mixtures for meadow establishment. Tr. Journal of Agriculture and Forestry, 22:13-20 (in Turkish).

Singh D. 2007. Grasses for hay and pasture. Proceeding, Idaho Alfalfa and Forage Conference, Twin Falls, ID University of Idaho Cooperative Extension, 26-27 February, USA.

Sheaffer CC, Hovin AV, Rabas DL. 1981. Yield and composition of orchardgrass, tall fescue and red canarygrass mixtures, Agronomy Journal, 73: 101-107.

Sleugh B, Kenneth JM, George R, Brummer EC. 2000. Binary legume-grass mixture improve forage yield, quality and seasonal distribution. Agronomy Journal, 92: 24-29.

Spandl E, Hesterman OB. 1997. Forage quality and alfalfa characteristics in binary mixtures of alfalfa and bromegrass or timoty. Crop Sciences, 37:1581-1585.
Ta TC, Faris MA. 1987. Effects of alfalfa proportions and clipping frequencies on timothy-alfalfa mixtures. II. nitrogen fixation and transfer. Agronomy Journal, 73: 820-824.

Weller RF, Cooper A. 2001. Seasonal changes in the crude protein concentration of mixed swards of white clover/perennial ryegrass grown without fertilizer in an organic farming system in the United Kingdom. Grass and Forage Science, 56: 92-95.

Willey RW, Osiru DS. 1972. Studies on mixture of maize and beans with particular reference to plant populations. Journal Agricultural Science, 79: 519-529.

Yavuz T. 2011. Determination of Artificial Pasture Mixtures for Dryland Conditions of Transitional Climate Zone of Black Sea Region. Gaziosmanpasa Uni. Graduate School of Natural and Applied Sci. Dep. of Field Crops (PhD Thesis) 251 p, Tokat (in Turkish).

Yavuz T, Karadag Y. 2016. Yield and quality performances of artificial pasture mixtures under dryland conditions. Iğdir Univ. J. Inst. Sci. \& Tech. 6(4): 155-163 (in Turkish).

Yolcu H, Serin Y, Tan M. 2010. The effects of seeding patterns, nitrogen and phosphorus fertilizations on production and botanical composition in lucerne-smooth bromegrass mixtures. Bulg. J. Agric. Sci., 16: 719-727. 